\title{
Testicular Yolk Sac Tumor, Microcystic Pattern
}

National Cancer Institute

\section{Source}

National Cancer Institute. Testicular Yolk Sac Tumor, Microcystic Pattern. NCI

Thesaurus. Code C39923.

A yolk sac tumor that arises from the testis and is characterized by the presence of a meshwork of small vacuolated cells resulting in a honeycomb appearance. 